\title{
THE RADIOCARBON DATA BASE OF JAPAN
}

\section{KUNIO OMOTO}

\author{
Radiocarbon Laboratory, Nihon University, 25-40, 3 Chome \\ Sakurajosui, Setagaya, Tokyo, 156, Japan
}

\begin{abstract}
About ten radiocarbon laboratories operate in Japan and have dated more than 25,000 samples since 1960. Geomorphic development and human activities since the last glaciation have been documented with radiocarbon determinations. In order to apply these dates more effectively, the author finds it necessary to create and maintain a radiocarbon database system, which he has been doing since 1985 , using a personal computer system linked to a telephone line. A researcher may access, search and retrieve data from the Radiocarbon Database System of Japan.
\end{abstract}

\section{INTRODUCTION}

In the early 1960s, Gakushuin University, Rikagaku Kenkyusho and the University of Tokyo began to publish their first date lists (Kigoshi \& Tomikura, 1960; Kigoshi, Tomikura \& Endo, 1961; Hamada, 1960; Yamasaki, Hamada \& Fujiyama, 1964; Sato, Sato \& Suzuki, 1968), but publication ceased with increased dating activities. Since then radiocarbon dates have been stored unpublished in their laboratories, and probably will never be reported in the conventional format of Radiocarbon.

About ten radiocarbon laboratories (Table 1) do conventional dating in Japan, and have made more than 25,000 determinations. It is no longer possible for a user to find a required date among thousands of dates.

TABLE 1

Current radiocarbon laboratories of Japan

\begin{tabular}{llcr}
\hline Lab code & Institute & Counting method & No. of dates* \\
\hline GaK & Gakushuin Univ & $\mathrm{C}_{2} \mathrm{H}_{2}$ & 17,000 \\
HIR & Hiroshima Univ & $\mathrm{CH}_{3} \mathrm{OH}$ & 250 \\
HIT & Hachinohe Coll & $\mathrm{C}_{6} \mathrm{H}_{6}$ & 20 \\
JGS & Geol Survey Japan & $\mathrm{C}_{6} \mathrm{H}_{6}$ & 500 \\
KN & Kanazawa Univ & $\mathrm{C}_{6} \mathrm{H}_{6}$ & 600 \\
KSU & Kyoto-Sangyo Univ & $\mathrm{CH}_{3} \mathrm{OH}$ & 1000 \\
N & Jap Isotope Assoc & $\mathrm{CO}_{2}$ & 5000 \\
NU & Nihon Univ & $\mathrm{CO}_{2}$ & 100 \\
NUTA & Nagoya Univ & $\mathrm{Tandem} \mathrm{Acc}_{2}$ & 500 \\
TH & Tohoku Univ & $\mathrm{CO}_{2} \& \mathrm{C}_{6} \mathrm{H}_{6}$ & 1700 \\
TK & Univ Tokyo & $\mathrm{C}_{2} \mathrm{H}_{2} \& \mathrm{C}_{6} \mathrm{H}_{6}$ & 500 \\
\hline
\end{tabular}

*Total number was estimated by the author 
Responsibilities of a radiocarbon laboratory include providing accurate dates to submitters as quickly as possible as well as useful information on the dates to other users. In order to accomplish the latter, we must collect and organize all radiocarbon data through computer technology.

The author has persisted in the implementation of the Radiocarbon Data Base System (RDS) (Omoto, 1985), which was designed to have two main functions, a data base and a Bulletin Board System (BBS). The data base enables the user to search, read and print out the required data from a microcomputer system linked to a telephone line. The BBS allows the user to "talk" with the system operator and send messages via a built-in "mail box."

The users of RDS are scattered throughout the country. For this reason, a centralized station seems best located in a metropolitan area, such as Tokyo, with subsidiary stations around it. Several dedicated lines, in addition to the central station, will prevent interference or cross-talk. The system should also have time-sharing and interactive features.

\section{DEVELOPMENT OF RDS}

\section{Hardware}

RDS hardware consists in a NEC computer system, connected to several modems and dedicated lines (Fig 1). Memory capability of the hard disk provides a minimum of $40 \mathrm{mb}$ (megabytes) with future enlargement to $80 \mathrm{mb}$.

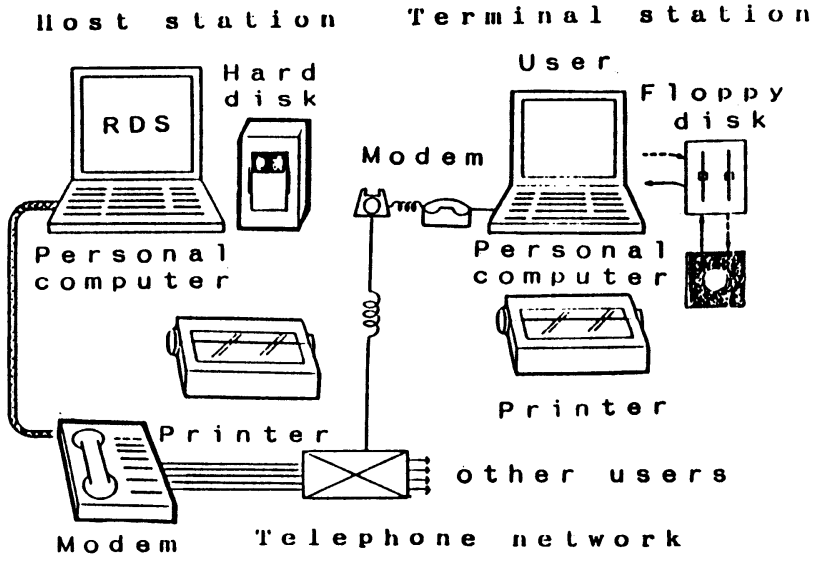

Fig 1. Hardware system for RDS host station

A multiplexer is normally used to control multi-circuits of the timesharing function, but this is handled by software. The dedicated lines can be extended up to five times by using an extension board. Each modem can set its baud rate either to 300 or 1200 bps fixed mode, or change it to 300 or 1200 bps automatically.

The system operator connects the cables to the equipment and sets or adjusts each dip-switch and jumper line of the RS-232C extension board. 
"Break-in level" is controlled in three dedicated lines by the software, but we have to set them manually for all five lines. Although the lines and the modems are limited to five, ca 100 users are able to access RDS each day.

\section{Software}

The structure for a record of a radiocarbon data file is of utmost importance. It is usually outlined on the laboratory submission form. The length of a data record is limited by the capacity of the hard disk. If we use a small disk, it is unable to store much information, while long records take a long time to search for data. In our case, one data file consists of 512 bytes; therefore, the hard disk is able to store information on ca 78,000 dates. We use one hard disk exclusively for data files and another $40 \mathrm{mb}$ disk for software and BBS.

The RDS software programs consist in Net Maker II, developed by Gijutsu Hyoronsha (1986) and Kiri, developed by Kanrikogaku Kenkyusho (1986). The system operator enters data onto the hard disk, using the Kiri

TABLE 2

${ }^{14} \mathrm{C}$ data display

***RADIOCARBON DATABASE OF THE NIHON UNIVERSITY, TOKYO JAPAN ${ }^{* * *}$

CODE NO: NU-88123

${ }^{14} \mathrm{C}$ AGE: 12,345

LONG. \& LAT.: 38/49/15N, 145/25/09E

DATE OF COLLECTION: 27/09/1987

ERRORS: $+250,-235$

ALTITUDE (m): $1235(-1.6)$

SUBMITTER: Ryutaro Higashi

LOCATION: Kurumayu, Naruko, Miyagi

MATERIAL: charcoal

FIELD OF STUDY: Archaeology

REFERENCE: Serizawa, 1975

OPERATOR: Kazuko Sakura

HALF-LIFE: 5570

REMARKS: Rec. sample 05/02/1988.

INSTITUTE: Fac. Lit., Tohoku Univ.

STRATIGRAPHY: Naruko tephra-D

KEYCODE: 10061231123

DATE OF DATING: $12 / 04 / 1988$

CHEM. ASSAY: 3A-Omoto, 1986

DC13/DC14: None

Rep. age 23/04/1988.

COMMENT: Reasonable age. Pub.: Miyagiken Hokubuno Iseki no Houshaseitanso nendai. Miyagiken Bunkazaihogoka (1988). 85p.

\begin{tabular}{c}
\hline DO YOU WANT TO SEARCH FOR OTHER DATA [Y/N]? [-] \\
DO YOU WANT TO CHANGE KEY-WORD [Y/N]? [-] \\
\hline
\end{tabular}

PUSH [HELP] KEY AT ANY MOMENT WHEN YOU NEED OUR »HELP«!

**RADIOCARBON DATABASE OF THE NIHON UNIVERSITY, TOKYO JAPAN**

database program. The format contains 21 fields (Table 2). The key-words, previously keyed into the program, are used to search for an item (eg, sample collection site, age range, discipline, etc). New key-words can be added to the system.

Both programs work on MS-DOS, written partly in assembler programming language. Thus, it runs quickly and efficiently. Of course, we guard against "break-in" in transmitting and receiving. Currently, common communication parameters are in use. Commands and maximum user time can be changed by rewriting the software programs. 


\section{SUMMARY}

The RDS, which is still being developed, will contribute to the progress of several scientific fields. Thousands of unpublished dates can be utilized by many scientists; new studies of statistical analyses of unpublished dates should also develop.

Finances for hardware, telephone lines and software should be provided by scientific grants. The problem of a copyright may remain unresolved, since a date belongs to both the submitter and director of the radiocarbon laboratory. Thus, permission should be obtained from the submitter for inclusion in RDS when a sample is submitted.

The author is interested in joining the International Radiocarbon Data Base (IRDB). But there are two problems: 1) computer language - the IRDB uses an IBM-compatible system and RDS operates on a NEC system; 2) our Japanese language will have to be translated into English. These are relatively minor problems, however, which will soon be resolved.

RDS is now operating on 1200 baud and with plans to speed up to 2400 bps in the near future. In order for the RDS to succeed in Japan as well as on a global scale, we need much cooperation from submitters, laboratories and users of radiocarbon data.

\section{ACKNOWLEDGMENTS}

The author would like to express his sincere appreciation to the Ito Kagakuzaidan and Nihon University for their financial support of this study. $\mathrm{He}$ also thanks Roy Switsur, University of Cambridge, and the editors of Radiocarbon for their suggestions and improvement of his English.

\section{REFERENCES}

Gijutsuhyoronsha, 1987, Net Maker II (Explanation text)*: Gijutsuhyoronsha Co Ltd, Tokyo, p 1-48.

Hamada, T, 1960, Radiocarbon dating I*: Rikagaku Kenkyusho Hokoku, no. 36, p 635.

Kanrikougakukenkyusho, 1986, Database system "Kiri" (Foundation of Kiri)*: Kanrikougakukenkyusho Co Ltd, Tokyo, p 1-228.

Kigoshi, K and Tomikura, Y, 1960, Variation of radiocarbon concentration in modern wood*: Chem Soc Japan Bull, v 33, p 1576-1580.

Kigoshi, K, Tomikura, Y and Endo, K, 1961, Gakushuin natural radiocarbon measurements I: Radiocarbon, v 4, p 84-94.

Omoto, K, 1985, An idea on the development of the radiocarbon data bank system*: Resume Japanese Quaternary Research, no. 16, p 114-115.

Omoto, K, 1988, A development of the radiocarbon data base system for Nihon University: Proc Inst Nat Sci Nihon Univ, v 24, in press.

Sato, J, Sato, T and Suzuki, H, 1968, University of Tokyo radiocarbon measurements I: Radiocarbon, $v$ 10, p 144-148.

Yamasaki, F, Hamada, T and Fujiyama, C, 1964, Riken natural radiocarbon measurements I: Radiocarbon, v 6, p 112-115.

*In Japanese 